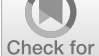

Check for

updates

Cite as

Nano-Micro Lett.

(2020) 12:100

Received: 19 January 2020

Accepted: 19 March 2020

Published online: 24 April 2020

(C) The Author(s) 2020

\section{Near-Infrared Light-Responsive Nitric Oxide Delivery Platform for Enhanced Radioimmunotherapy}

\author{
Xuanfang Zhou ${ }^{1}$, Zhouqi Meng ${ }^{1}{ }^{凶}$, Jialin She ${ }^{1}$, Yaojia Zhang ${ }^{1}$, Xuan $\mathrm{Yi}^{2}$, Hailin Zhou $^{2}$, \\ Jing Zhong ${ }^{2}$, Ziliang Dong ${ }^{1}$, Xiao Han ${ }^{1}$, Muchao Chen $^{1}$, Qin Fan ${ }^{1}$, Kai Yang ${ }^{2}$, \\ Chao Wang ${ }^{1 凶}$ \\ $\triangle$ Zhouqi Meng, mengzhouqi@gmail.com; Chao Wang, cwang@suda.edu.cn \\ 1 Institute of Functional Nano and Soft Materials (FUNSOM), Jiangsu Key Laboratory \\ for Carbon-Based Functional Materials and Devices, Soochow University, Suzhou 215123, Jiangsu, \\ People's Republic of China \\ 2 State Key Laboratory of Radiation Medicine and Protection, School of Radiation Medicine and Protection \\ and School for Radiological and Interdisciplinary Sciences (RAD-X), Collaborative Innovation Center \\ of Radiation Medicine of Jiangsu Higher Education Institutions, Soochow University, Suzhou 215123, \\ Jiangsu, People's Republic of China
}

\title{
HIGHLIGHTS
}

- $\mathrm{Ag}_{2} \mathrm{~S}$ NO delivery platforms maximize radiotherapy effects remarkably to inhibit the tumor growth.

- Immunosuppressive tumor microenvironment was improved by $\mathrm{Ag}_{2} \mathrm{~S}$ NO delivery system, significantly enhancing the anti-PD-L1 immune checkpoint blockade therapy.

\begin{abstract}
Radiotherapy (RT) is a widely used way for cancer treatment. However, the efficiency of RT may come with various challenges such as low specificity, limitation by resistance, high dose and so on. Nitric oxide (NO) is known a very effective radiosensitizer of hypoxic tumor. However, NO cannot circulate in body with high concentration. Herein, an NIR light-responsive NO delivery system is developed for controlled and precisely release of NO to hypoxic tumors during radiotherapy. Tert-Butyl nitrite, which is an efficient NO source, is coupled to $\mathrm{Ag}_{2} \mathrm{~S}$ quantum dots (QDs). NO could be generated and released from the $\mathrm{Ag}_{2} \mathrm{~S}$ QDs effectively under the NIR irradiation due to the thermal effect. In addition, $\mathrm{Ag}$ is also a type of heavy metal that can benefit the RT therapy. We demonstrate that $\mathrm{Ag}_{2} \mathrm{~S}$ NO delivery platforms remarkably maximize radiotherapy effects to inhibit tumor growth in CT26 tumor model. Furthermore, immunosuppressive tumor microenvironment is improved by our NO delivery system, significantly enhancing the anti-PD-L1 immune checkpoint blockade therapy. $100 \%$ survival rate is achieved by the radio-immune combined therapy strategy based on the $\mathrm{Ag}_{2} \mathrm{~S} \mathrm{NO}$ delivery platforms. Our results suggest the promise of $\mathrm{Ag}_{2} \mathrm{~S}$ NO delivery platforms for multifunctional cancer radioimmunotherapy.
\end{abstract}

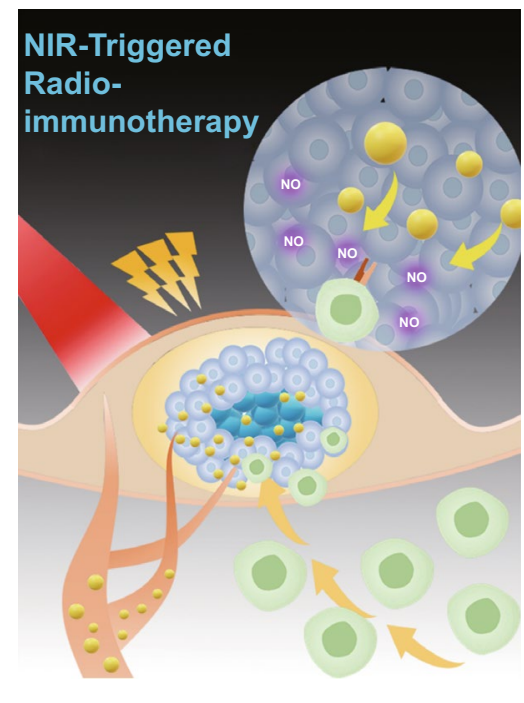

KEYWORDS NO delivery; Radio sensitivity; Multifunctional agent; Radioimmunotherapy; Drug delivery 


\section{Introduction}

Radiotherapy (RT), which uses radiation to kill cancer cells by damaging DNA, is widely used in clinical applications [1-4]. As one type of RT, external beam radiotherapy is a localized therapy that applies high-energy beams to target directly at the tumor. However, the efficacy of RT can be influenced by the tumor hypoxic microenvironment, resulting in the resistance of tumor to RT $[4,5]$. Meanwhile, various severe side effects associated with RT are still one of major challenges in clinical practice. How to make cancer cells more sensitive to RT, whilst avoiding or minimizing damage to surrounding healthy tissue is urgent to be addressed $[6,7]$.

In addition to many heavy metals (e.g., gold, platinum, silver) that could enlargement radiation effects, nitric oxide (NO) is known a very effective radiosensitizer of hypoxic tumor as well [8-13]. It has previously been shown that DNA damage induced by NO during radiation is remarkably enhanced [2, 9, 14-18]. Recent studies also indicate that NO can regulate the functional of many immune cells including macrophages, $\mathrm{T}$ lymphocytes and antigen-presenting cells, making them more active against the infection and cancer [19-21]. However, NO cannot circulate in body with high concentration (half-life is less than $5 \mathrm{~s}$ and diffusion radius is less than $40 \mu \mathrm{m}$ ) and it can participate in many pathways to disturb internal environment due to their high bioactivity $[13,17,22-27]$. A potential strategy to develop a system for controlled and precisely release of NO to hypoxic tumors during radiotherapy holds great promise to improve the RT [7, 16, 28-30].

Numerous NO donors can be used to deliver and release NO by various triggers, such as $\mathrm{pH}$, heat and light [31-42]. Semiconductor metal sulfide materials such as $\mathrm{Ag}_{2} \mathrm{~S}$ quantum dots (QDs) have been widely used in optical imaging, photoacoustic imaging, sensing and photothermal therapy [43]. Ag is also a type of heavy metal that can benefit the RT therapy. Here, we described an NIR-induced, thermaltriggered $\mathrm{NO}$ release system based on the $\mathrm{Ag}_{2} \mathrm{~S}$ QDs for the improvement in RT. In our system, proteins (such as BSA or OVA) were used to modify the $\mathrm{Ag}_{2} \mathrm{~S}$ QDs; then, the NO donor tert-butyl nitride (TBN) could be further coupled to the proteins to form $\mathrm{Ag}_{2} \mathrm{~S} @ \mathrm{BSA}-\mathrm{SNO}$ nanoparticles (Fig. 1a).We demonstrated that NO could be generated and released from the $\mathrm{Ag}_{2} \mathrm{~S}$ QDs effectively under the NIR irradiation in vitro [43-47]. In the mice tumor model, $\mathrm{Ag}_{2} \mathrm{~S}$ QDs could accumulate at the tumor site by EPR effect. We demonstrated that NIR irradiation made tumor more sensitive to the following RT. Synergetic effects were achieved, which could eliminate most established CT26 tumor in nude mice. Moreover, we further demonstrated that this strategy could induce specific antitumor immune response in B6 mice bearing B16F10 tumor, significantly increasing antiPD-L1 therapy response, making our $\mathrm{Ag}_{2} \mathrm{~S}$ QDs platform promise in cancer radioimmunotherapy.

\section{Materials and Methods}

\subsection{Materials}

Albumin from bovine serum (BSA) was bought from Beijing J\&K Scientific. Tert-butyl nitride (TBN) was provided by Alfa Aesar. Silver nitrate $\left(\mathrm{AgNO}_{3}\right)$, sodium sulfide $\left(\mathrm{Na}_{2} \mathrm{~S}\right)$, EDTA (ethylenediaminetetraacetic acid) and sodium hydroxide $(\mathrm{NaOH})$, methyl alcohol and dichloromethane were bought from China National Pharmaceutical Industry Corporation Ltd. PBS buffer was got from Solarbio. Traut's reagent was provided by BioVision. Nitric oxide assay kit was bought from Beyotime. Ultrapure water was obtained from a Milli-Q system. Antibody was bought from BioLegend and Invitrogen.

\subsection{Preparation and Characteristic of $\mathrm{Ag}_{2} \mathrm{~S} @ \mathrm{BSA}-\mathrm{SNO}$ Nanoparticles}

\subsubsection{Synthesis of $\mathrm{Ag}_{2} \mathrm{~S} @ \mathrm{BSA}$}

According to the previous work, $\mathrm{Ag}_{2} \mathrm{~S} @ \mathrm{BSA}$ was produced by mineralization of bovine serum albumin. In brief, $250 \mathrm{mg}$ BSA powder was dispersed in $8 \mathrm{~mL}$ ultrapure water, and then $2 \mathrm{~mL} 0.2 \mathrm{mM} \mathrm{AgNO}_{3}$ solution was dropped in BSA solutions. The system became turbid. $\mathrm{NaOH}$ solutions were used to regulate the whole system's $\mathrm{pH}$ value around 12 to make a suitable condition for crystal growth. Finally, there was $18.2 \mathrm{mg} \mathrm{Na}_{2} \mathrm{~S}$ which provides anion for $\mathrm{Ag}_{2} \mathrm{~S}$ crystal added. With reaction going on, color of solution changed from yellow to sepia. After 4-h stirring under $55^{\circ} \mathrm{C}, \mathrm{Ag}_{2} \mathrm{~S} @$ BSA solution was obtained. 


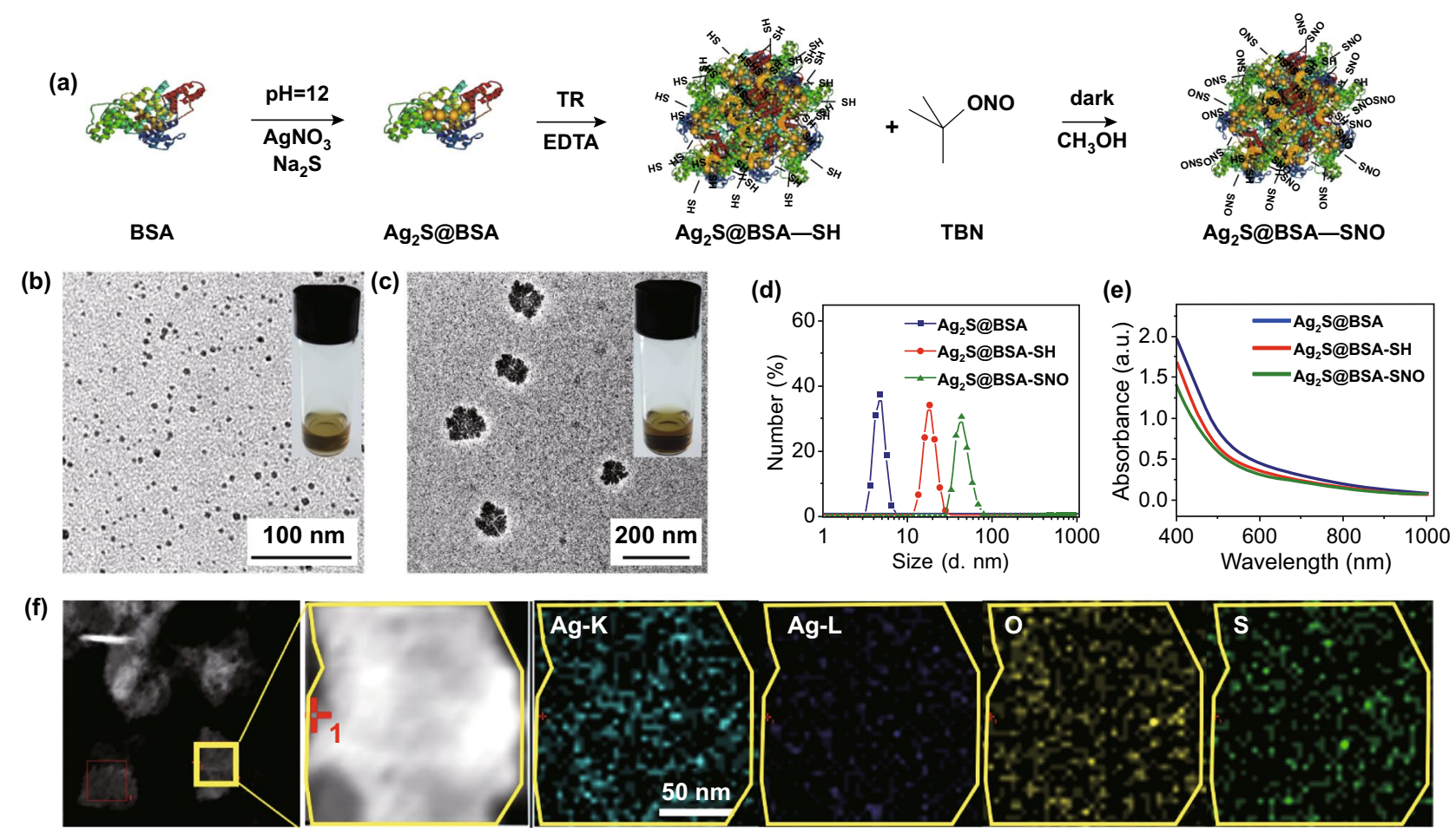

Fig. 1 Schematic illustration and characterization of $\mathrm{Ag}_{2} \mathrm{~S} @ \mathrm{BSA}-\mathrm{SNO}$ nanoparticles. a A schematics illustration showing $\mathrm{Ag}_{2} \mathrm{~S}$ growth in BSA nanocage and NO donor function group formation. b, $\mathbf{c}$ TEM images of $\mathrm{Ag}_{2} \mathrm{~S} @ \mathrm{BSA}$ and $\mathrm{Ag}_{2} \mathrm{~S} @ \mathrm{BSA}-\mathrm{SNO}$. Inset: picture of $\mathrm{Ag}_{2} \mathrm{~S} @ \mathrm{BSA}$ and $\mathrm{Ag}_{2} \mathrm{~S} @ \mathrm{BSA}-\mathrm{SNO}$ solution $\left(20 \mathrm{mg} \mathrm{mL} \mathrm{m}^{-1}\right.$ ). d Dynamic light scattering (DLS) analysis of $\mathrm{Ag}_{2} \mathrm{~S} @ \mathrm{BSA}, \mathrm{Ag}_{2} \mathrm{~S} @ \mathrm{BSA}-\mathrm{SH}$ and Ag $\mathrm{S} @ \mathrm{BSA}-\mathrm{SNO}$. e UV-Vis-NIR spectra of $\mathrm{Ag}_{2} \mathrm{~S} @ \mathrm{BSA}, \mathrm{Ag}_{2} \mathrm{~S} @ \mathrm{BSA}-\mathrm{SH}$ and $\mathrm{Ag}_{2} \mathrm{~S} @ \mathrm{BSA}-\mathrm{SNO}$ solution. f STEM image of Ag $\mathrm{S}_{2}$ S BSA-SNO nanoparticles to show elements' locations

\subsubsection{Synthesis of $\mathrm{Ag}_{2} \mathrm{~S} @ \mathrm{BSA}-\mathrm{SH}$}

$\mathrm{Ag}_{2} \mathrm{~S} @ \mathrm{BSA}$ solution containing $10 \mathrm{mg}$ BSA was added to $5 \mathrm{~mL} 5 \mathrm{mM}$ EDTA solution (dissolved by PBS buffer) and then added $1 \mathrm{mg}$ Traut's reagent for stirring $2 \mathrm{~h}$ under $4{ }^{\circ} \mathrm{C}$ to modify surface function group of BSA nanoparticles. The production got from this procedure would be dialysis in DI water to remove extra saline ions.

\subsubsection{Synthesis of $A g_{2} S @ B S A-S N O$}

The concentration of $\mathrm{Ag}_{2} \mathrm{~S} @ \mathrm{BSA}-\mathrm{SH}$ solution was concentrated through ultrafiltration with a $100 \mathrm{kD}$ Millipore to decrease the volume of water. Methyl and dichloromethane $\left(\mathrm{V}_{\mathrm{MeOH}} / \mathrm{V}_{\mathrm{CH}_{2} \mathrm{Cl}_{2}}=5\right)$ were mixed to dissolve TBN, which was the nitric oxide donor. Condensed $\mathrm{Ag}_{2} \mathrm{~S} @ \mathrm{BSA}$ SH solution with $10 \mathrm{mg}$ BSA was added in $5 \mathrm{~mL}$ methyl when stirring. $1 \mathrm{~mL}$ TBN solution was mixed with methyl/ dichloromethane solution and then added to $\mathrm{Ag}_{2} \mathrm{~S} @ \mathrm{BSA}-\mathrm{SH}$ solution. The following reaction was kept in dark environment and under $4{ }^{\circ} \mathrm{C}$. Finally, organic solvent was removed by rotary evaporation and then $\mathrm{Ag}_{2} \mathrm{~S} @ \mathrm{BSA}-\mathrm{SNO}$ was re-dissolved by PBS and then stored in $4{ }^{\circ} \mathrm{C}$. During the process, free $\mathrm{Ag}_{2} \mathrm{~S}$ was removed during the dialysis process, while the extra TBN was removed with organic solvent during the rotary evaporation [16].

\subsection{Characterization}

Dynamic light scattering (DLS) was measured by Malvern, NANO ZS90, while TEM images were got from Tecnai G2 F20 field emission transmission electron microscopy. The UV-Vis spectra of different concentrations of $\mathrm{Ag}_{2} \mathrm{~S} @$ BSA-SNO solutions were detected by ultraviolet and visible spectrophotometer, and the concentration was determined by silver anion. The photoacoustic signals of materials were measured by the PA mode of PA imaging system (FUJIFILM VisualSonics Inc.). 


\subsection{NO Generation Tests}

The production of NO was tested by nitric oxide assay kit. In short, $\mathrm{Ag}_{2} \mathrm{~S} @ \mathrm{BSA}-\mathrm{SNO}$ samples were incubated under $37{ }^{\circ} \mathrm{C}$ or laser-irradiated which caused different temperatures. The released $\mathrm{NO}$ would convert into nitrite; after that, the Griess agent reacted with nitrite to form diazo compound. Finally, the signal of diazo compound was detected by microplate reader at $540 \mathrm{~nm}$. There were at least three parallel samples at each condition.

\subsection{NIR Photothermal Heating}

$\mathrm{Ag}_{2} \mathrm{~S} @ \mathrm{BSA}$-SNO nanoparticles with different concentrations in PBS buffer were irradiated by $808 \mathrm{~nm}$ semiconductor laser device for $5 \mathrm{~min}\left(1.0 \mathrm{~W} \mathrm{~cm}^{-2}\right)$. And the real-time temperature change was monitored by a thermal imaging temperature monitoring system FLIR-A300 (FILR Systems Inc.).

\subsection{Cell Experiment}

\subsubsection{Cell Culture}

The CT26 murine colonic cancer cells were cultured in RPMI-1640 culture medium in a humidified incubator at $37{ }^{\circ} \mathrm{C}$ under $5 \% \mathrm{CO}_{2}$. The 1640 culture medium was added with $10 \%$ fetal bovine serum (FBS) and $1 \%$ penicillin/ streptomycin, while the B16F10 murine melanoma cells were cultured in DMEM/high-glucose culture medium that contained 10\% FBS and 1\% penicillin/streptomycin in one incubator.

\subsubsection{Cytotoxicity Experiment}

The viability of CT26 cells exposed to $\mathrm{Ag}_{2} \mathrm{~S} @ \mathrm{BSA}-\mathrm{SNO}$ and photothermal effect was assessed by methyl thiazolyl tetrazolium (MTT) assay. $10^{4} \mathrm{CT} 26$ cells were pre-cultured in 96-well plate for $24 \mathrm{~h}$ before adding $\mathrm{Ag}_{2} \mathrm{~S} @ \mathrm{BSA}-\mathrm{SNO}$ solution. After that, RPMI-1640 was removed and new culture was added with different concentrations of $\mathrm{Ag}_{2} \mathrm{~S} @$ BSA-SNO solution and co-cultured for another $24 \mathrm{~h}$. Before adding MTT solution, all solutions were removed and 96-well plate was washed twice with PBS buffer. After 4-h incubation, MTT solution was removed carefully, 100 $\mu \mathrm{L}$ DMSO was added per well, and the absorption was tested at $570 \mathrm{~nm}$ by a microplate reader after 10-min vibration. Each condition was performed with six replicates.

The hemolytic assay was performed using fresh mice red blood cells. PBS was used to re-suspend RBCs. $\mathrm{Ag}_{2} \mathrm{~S} @$ BSA-SNO NPs were then added to RBC solution, and the same volume of water was set as positive control. The supernatant was obtained by centrifuging samples $1 \mathrm{~h}$ later under $37{ }^{\circ} \mathrm{C}$. UV absorbance of supernatant at $545 \mathrm{~nm}$ was measured and recorded. The hemolysis ratio was calculated by division of the difference between experimental group/positive control group and negative control group.

\subsubsection{PI/AM Double Staining}

$10^{6}$ cells per $35-\mathrm{mm}$ dish were incubated for $24 \mathrm{~h}$ before any treatment. And then, added $\mathrm{Ag}_{2} \mathrm{~S} @ \mathrm{BSA}$ solution for a final concentration is $100 \mu \mathrm{g} \mathrm{mL}^{-1}$. About 4-h co-culturing, the cell was lighted by $808 \mathrm{~nm}$ laser $\left(1.5 \mathrm{~W} \mathrm{~cm}^{-2}\right.$, $\left.42{ }^{\circ} \mathrm{C}\right)$. The cells after different processing time were washed with PBS for several times to remove all materials. And then the cells were co-stained with calcein AM and propidium iodide (PI) for 20 min to identify if they were living or dead. Then, the cells were imaged by confocal fluorescence microscope (Zeiss).

\subsubsection{Cell Clonogenic Experiment}

Different mounts of CT26 cells $(125,1000$ cells per well corresponding to $0 \mathrm{~Gy}$ and $6 \mathrm{~Gy}$ ) were pre-seeded into 6-well plates. After $24 \mathrm{~h}$ cultured as usual at normal environment, $\mathrm{Ag}_{2} \mathrm{~S} @ \mathrm{BSA}$ or $\mathrm{Ag}_{2} \mathrm{~S} @ \mathrm{BSA}-\mathrm{SNO}$ was added to incubate cells for another $4 \mathrm{~h}$. After that, plates were exposed to irradiation of laser device $\left(1.5 \mathrm{~W} \mathrm{~cm}^{-2}\right.$, $42{ }^{\circ} \mathrm{C}, 5 \mathrm{~min}$ ) or X-ray (6 Gy) or both of them. Next, fresh RPMI-1640 medium (1\% penicillin/streptomycin, $10 \%$ fetal calf serum) was used to culture cells for additional 7 days. Finally, cells were rinsed with PBS for three times and fixed by methyl for around $15 \mathrm{~min}$ to be colored with crystal violet about $30 \mathrm{~min}$. And then, cell colonies were counted and calculated for surviving fraction $=$ (survival colonies $) /($ seeded cells $) \times \%$. The average survival was calculated by three replicates. 


\subsubsection{Cell $\gamma$-H2AX Immunofluorescence Staining}

In the experiment of CT26 cells $\gamma$-H2AX immunofluorescence staining, $10^{4} / \mathrm{mL}$ CT26 cells were pre-seeded in a 24-well plate. And after $18 \mathrm{~h}$ being cultured, cells were added with different kinds of solutions $\left(\mathrm{Ag}_{2} \mathrm{~S} @ \mathrm{BSA}, \mathrm{Ag}_{2} \mathrm{~S} @\right.$ BSA-SNO or same volume of PBS). After co-cultured lasted for $6 \mathrm{~h}$, cells received laser irradiation or X-ray irradiation or both of them. The power of $808 \mathrm{~nm}$ laser was $1.5 \mathrm{~W} \mathrm{~cm}^{-2}$ ( $5 \mathrm{~min}$ ), while the X-ray irradiation dose was $6 \mathrm{~Gy}$. After $60 \mathrm{~min}$, the cells were washed with PBS and fixed by $4 \%$ formaldehyde for $15 \mathrm{~min}$. $1 \%$ bovine serum albumin was used as blocking solution for treating cells about $1 \mathrm{~h}$. After that, the blocking solution was removed and anti-phosphohistone $\gamma$-H2AX mouse monoclonal antibody (dilution was 1:1000) was used to stain cells at $4{ }^{\circ} \mathrm{C}$ overnight. After extra antibody was washed with PBS, cells were treated by Cy3conjugted secondary antibody at $37{ }^{\circ} \mathrm{C}$ for $1 \mathrm{~h}$. Cells were imaged by a confocal fluorescence scanning microscopy (Zeiss). The area \% of DNA damage in every sample was analyzed by ImageJ software.

\subsection{Animal Experiment}

C57BL/6 and BALB/c Nude mice (6-10 weeks) were purchased from Changzhou Cavens Experimental Animal Co. Ltd. Mice were treated under protocols approved by the Institutional Animal Care and Use Committee of Soochow University.

\subsubsection{PA Imaging}

CT26 tumor-bearing nude mice were i.v. injected with 200 $\mu \mathrm{L} \mathrm{Ag} \mathrm{g}_{2} \mathrm{~S} @ \mathrm{BSA}-\mathrm{SNO}$ nanoparticles $\left(20 \mathrm{mg} \mathrm{mL}^{-1}\right)$ solution or PBS. And then, the tumor region was imaged with an PA imaging system under $730 \mathrm{~nm}$ excitation wavelength at different time intervals after injection (VisualSonics Vevo 2100 LAZER).

\subsubsection{IR Thermal Imaging In Vivo}

After 24-h injection of $200 \mu \mathrm{L} \mathrm{Ag}_{2} \mathrm{~S} @ \mathrm{BSA}-\mathrm{SNO}, \mathrm{Ag}_{2} \mathrm{~S} @$ BSA or PBS solutions, CT26 tumor-bearing mice were irradiated by $808 \mathrm{~nm}$ laser device with $1.0 \mathrm{~W} \mathrm{~cm}^{-2}$ power and lasted for about $10 \mathrm{~min}$ to do temperature change recording. IR images were monitored timely by the IR thermal camera.

\subsubsection{Biodistribution and Blood Circulation}

CT26-bearing nude mice were intravenous injected with $200 \mu \mathrm{L} 10 \mathrm{mg} \mathrm{mL}{ }^{-1} \mathrm{Ag}_{2} \mathrm{~S} @ \mathrm{BSA}-\mathrm{SNO}$ solution. Blood samples were obtained through vena ophthalmic at specific time points. Organs were obtained after one day post-injection. And then, aqua regia was used to dissolve tissues and blood samples. The clear solution was filtered by $0.22-\mu \mathrm{m}$ filter membrane. Whereafter, the concentration of $\mathrm{Ag}^{+}$was detected by inductively coupled plasma source mass spectrometer (Aurora M90). And the values of ID\% were calculated by concentration of $\mathrm{Ag}^{+}$to the mass of tissue or blood.

\subsubsection{Immunohistochemistry}

Tumor region of mice was irradiated by $808 \mathrm{~nm}$ laser $\left(1.0 \mathrm{~W} \mathrm{~cm}^{-2}\right)$ about $10 \mathrm{~min}$; then, the mice were injected with pimonidazole hydrochloride $\left(60 \mathrm{mg} \mathrm{kg}^{-1}\right.$, Hypoxiaprobe-1 Plus Kit, Hypoxyprobe Inc.) immediately. The Hypoxiaprobe-1 was injected by intraperitoneal injection. And after 30-min post-injection, tumor was dissected and fixed in O.C.T. glue under $-80{ }^{\circ} \mathrm{C}$. For further immunofluorescence staining, tumors were cut into $10-\mu \mathrm{m}$ sections through frozen cutting. And then the sections were fixed by acetone and blocked by $1 \%$ BSA solution. Hypoxyprobe anti-pimonidazole primary antibody and 488-conjugated goat anti-mouse secondary antibody was stained in the light of kit's introductions. Anti-CD31 mouse monoclonal primary antibody and rhodamine-conjugated secondary antibody were used to stain blood vessels. Nuclei were dyed by DAPI. Extra antibody was washed with PBS. Finally, sections were scanned by confocal fluorescence microscope (Zeiss) to get the image.

\subsubsection{Tumor Treatment In Vivo}

When tumor size achieved about $125 \mathrm{~mm}^{3}$, nude mice bearing CT26 tumor were divided into eight groups (five mice per group): (1) untreated; (2) X-ray irradiation; (3) $\mathrm{Ag}_{2} \mathrm{~S} @ \mathrm{BSA}-\mathrm{SNO}$; (4) $\mathrm{Ag}_{2} \mathrm{~S} @ \mathrm{BSA}+$ laser; (5) 
$\mathrm{Ag}_{2} \mathrm{~S} @ \mathrm{BSA}-\mathrm{SNO}+\mathrm{X}$-ray; (6) $\mathrm{Ag}_{2} \mathrm{~S} @ \mathrm{BSA}-\mathrm{SNO}+$ laser; (7) $\mathrm{Ag}_{2} \mathrm{~S} @ \mathrm{BSA}+$ laser + X-ray; and (8) $\mathrm{Ag}_{2} \mathrm{~S} @ \mathrm{BSA}-$ $\mathrm{SNO}+$ laser + X-ray. Each mouse was injected with $200 \mu \mathrm{L}$ solutions $\left(\mathrm{Ag}_{2} \mathrm{~S} @ \mathrm{BSA}\right.$ or $\mathrm{Ag}_{2} \mathrm{~S} @ \mathrm{BSA}-\mathrm{SNO}$, respectively, $20 \mathrm{mg} \mathrm{mL}^{-1}$ ) through caudal vein. After $4 \mathrm{~h}$, mice in groups 4, 6, 7 and 8 were exposed to $808 \mathrm{~nm}$ laser $\left(1 \mathrm{~W} \mathrm{~cm}^{-2}\right.$, $42{ }^{\circ} \mathrm{C}, 10 \mathrm{~min}$ ), while mice in groups 2,5 and 8 which received radiotherapy were exposed to X-ray (6 Gy). Particularly, groups 7 and 8 that received both of the treatments were irradiated by $808 \mathrm{~nm}$ laser first. The body weight and tumors' size were measured at day 0 before treatment. The body weight and tumor size were recorded every two days until the tumor size of one mouse in a group reached over $1000 \mathrm{~mm}^{3}$.

\subsubsection{Immunotherapy and Immunological Evaluation of $\mathrm{Ag}_{2} \mathrm{~S} @ \mathrm{OVA}-\mathrm{SNO}$-Treated B16F10 Tumor In Vivo}

For in vivo immunotherapy, B16F10 tumor model was built on B6 mice. When tumor size was around $100 \mathrm{~mm}^{3}$, mice were divided into four groups (eight mice per groups): (1) untreated; (2) $\alpha$-PD-L1; (3) $\mathrm{Ag}_{2} \mathrm{~S} @ \mathrm{OVA}-\mathrm{SNO}+$ laser + X-ray; and (4) $\mathrm{Ag}_{2} \mathrm{~S} @ \mathrm{OVA}-$ $\mathrm{SNO}+$ laser $+\mathrm{X}$-ray $+\alpha$-PD-L1. Mice in group 2 were injected with $\alpha$-PD-L1 $\left(1 \mathrm{mg} \mathrm{kg}^{-1}\right.$, three injections during 7 days), while group 4 needed injection $\alpha$-PD-L1 as well. Mice in group 3 and group 4 were injected with $25 \mu \mathrm{L}$ $\mathrm{Ag}_{2} \mathrm{~S} @$ OVA-SNOsolution $\left(5 \mathrm{mg} \mathrm{mL}^{-1}\right)$, and then tumor was irradiated by $808 \mathrm{~nm}$ laser $\left(1 \mathrm{~W} \mathrm{~cm}^{-2}, 42{ }^{\circ} \mathrm{C}, 10 \mathrm{~min}\right)$. After laser irradiation, mice were exposed to X-ray (6 Gy). Tumor size and body weight were monitored every two days.

At day 4 after treatment, three mice from every group were mercy euthanatized and blood samples and tumor tissue were collected for immunological evaluation. A part of tumor tissue was fixed by O.C.T. glue to make frozen section for immunological staining. And the last part was homogenized into single-cell suspensions according to the well-established protocol. Those cells were stained with anti-CD8-PE, anti-CD4-APC and anti-CD3-FITC to measure CTLs in tumor tissue. And cells stained with anti-F4/80-FITC, anti-CD80-APC or anti-CD206-APC and anti-CD11b-PE were used to analyze microphage type I or microphage type II accordingly. The stained cells were tested by flow cytometry (BD C6 Plus). The serum was got by centrifuging blood samples (3000 rpm, $5 \mathrm{~min}, 4{ }^{\circ} \mathrm{C}$ ). The IFN- $\gamma$ cytokine was tested by ELISA kit (Invitrogen), and all options are going according to kit's introduction.

\subsubsection{Histology Analysis}

Mice were killed, and tumors and organ tissue were harvested immediately. The tissues were fixed by formalin for hematoxylin and eosin staining.

\section{Results and Discussion}

According to the previous study [43], $\mathrm{Ag}_{2} \mathrm{~S}$ crystal was formed with bovine serum albumin (BSA), which provided a suitable cavity for $\mathrm{Ag}_{2} \mathrm{~S}$ growth under $55^{\circ} \mathrm{C}$. The synthesized $\mathrm{Ag}_{2} \mathrm{~S} @ \mathrm{BSA}$ nanoparticles displayed homogenous sizes with diameter about $5 \mathrm{~nm}$ as shown by TEM and DLS analyses (Fig. 1b-d, f). The ratio of $\mathrm{Ag}_{2} \mathrm{~S}$ to BSA is about $0.98 \%$ (wt\%). To conjugate the NO source to the $\mathrm{Ag}_{2} \mathrm{~S} @ \mathrm{BSA}$ NPs, the surface groups of BSA were changed into -SNO group after sulfhydryl reacts with TBN (Fig. 1a). With the -SNO modification, the diameter of the SNO-coupled $\mathrm{Ag}_{2} \mathrm{~S} @ \mathrm{BSA}$ nanoparticles ( $\mathrm{Ag}_{2} \mathrm{~S} @ \mathrm{BSA}-\mathrm{SNO} \mathrm{NPs}$ ) exhibited an increase in diameter with an average hydrodynamic size about $50 \mathrm{~nm}$ (Fig. 1d), probably due to the self-assemble of $\mathrm{Ag}_{2} \mathrm{~S} @ \mathrm{BSA}$ NPs. Besides, the nanoparticles exhibited good colloidal stability in the PBS (Fig. S1).

$\mathrm{Ag}_{2} \mathrm{~S} @ \mathrm{BSA}-\mathrm{SNO}$ had strong absorption within the visible and NIR regions, making it as a great agent for photothermal therapy and photoacoustic imaging (Fig. 1e). As shown in Fig. 2a, the $\mathrm{Ag}_{2} \mathrm{~S} @$ BSA-SNO NPs could be easily heated by NIR laser ( $808 \mathrm{~nm}$ ) with the exposure time and concentration dependencies (Fig. 2b). In addition, the solution had a good stability after several times of laser irradiation (Fig. 2d). The $\mathrm{Ag}_{2} \mathrm{~S}$ quantum dots also had stable and great photothermal effect under different laser power irradiations according to the previous study [43, 48-51]. The photoacoustic response of $\mathrm{Ag}_{2} \mathrm{~S} @$ BSA-SNO under certain wavelength was also examined by VEVO laser imaging system (Fig. 2e). It was shown that 730-nm-wavelength light irradiation resulted in the highest intensity of PA signals. A near-linear relationship was also observed between the concentration of $\mathrm{Ag}_{2} \mathrm{~S} @$ BSA-SNO NPs and PA signals intensity (Fig. 2f). As the $\mathrm{Ag}_{2} \mathrm{~S} @ \mathrm{BSA}-\mathrm{SNO}$ NPs possessed an NIR-II emission (Fig. 
(a)

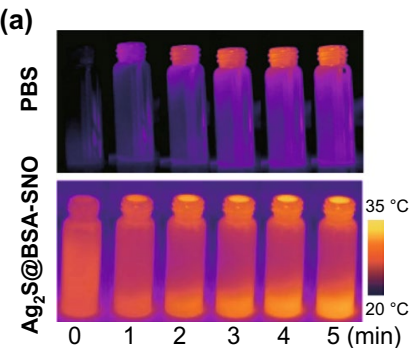

(e)

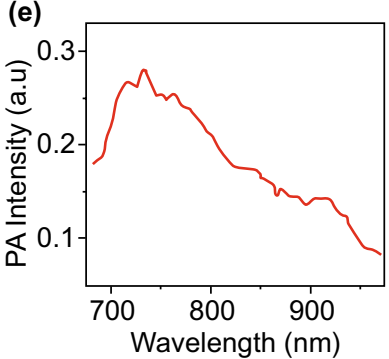

(b)

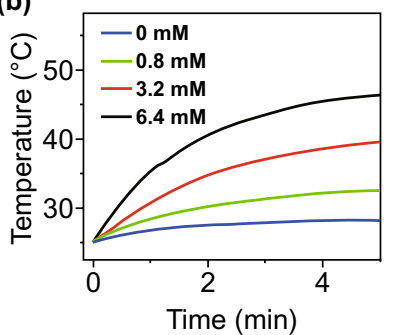

(f)

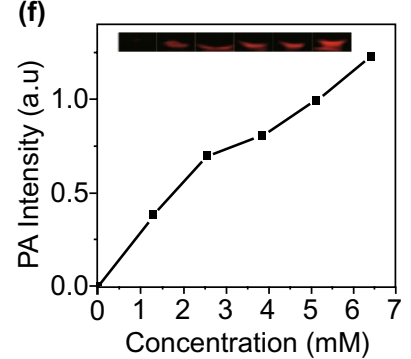

(c)

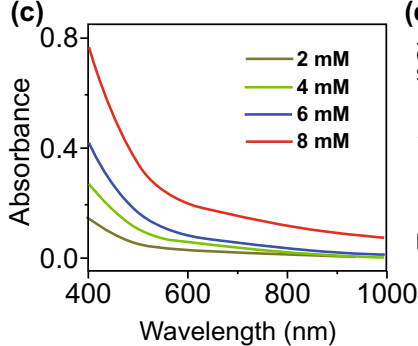

(g)

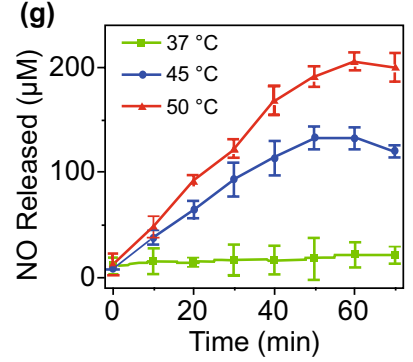

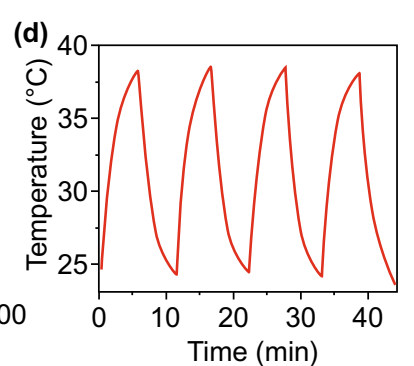

(h)

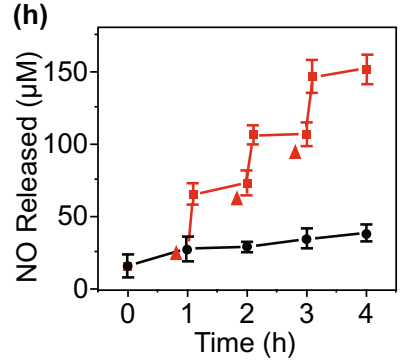

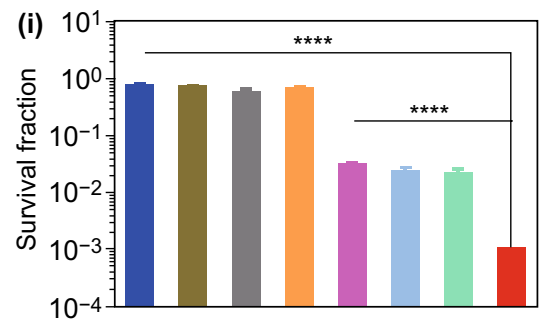
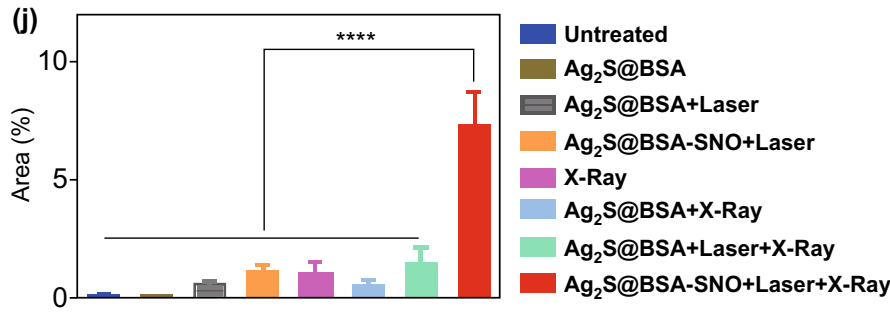

(k)
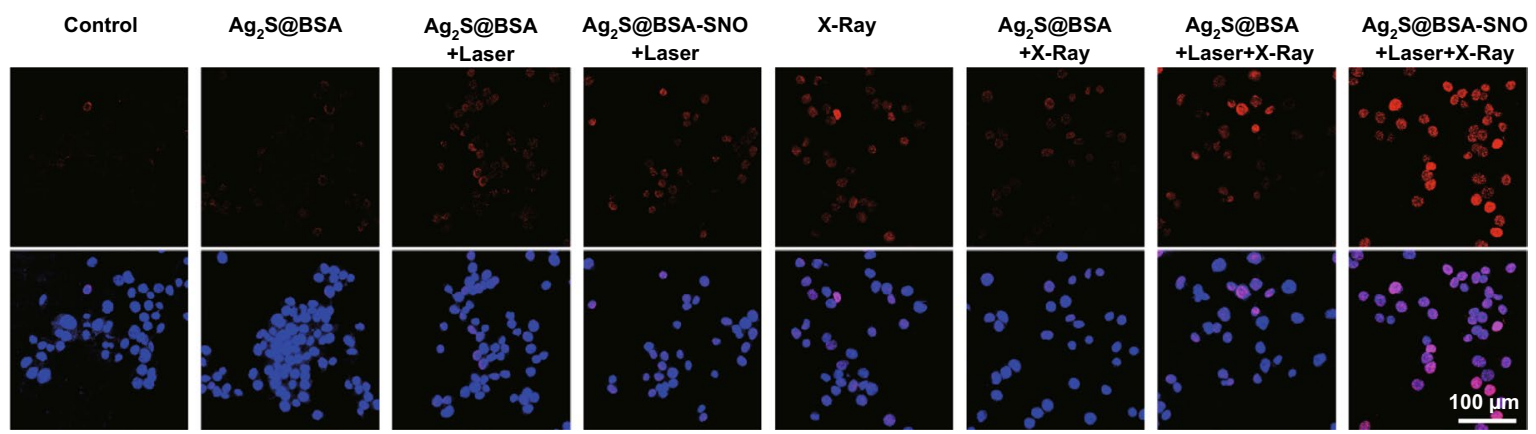

Fig. 2 NO-controlled release from $\mathrm{Ag}_{2} \mathrm{~S} @ \mathrm{BSA}$-SNO nanoparticles and in vitro therapeutic efficiency of X-ray enhanced by Ag 2 S@BSA-SNO nanoparticles. a IR images of $\mathrm{Ag}_{2} \mathrm{~S} @ \mathrm{BSA}$ and $\mathrm{Ag}_{2} \mathrm{~S} @ \mathrm{BSA}-\mathrm{SNO}$ solution under $808 \mathrm{~nm}$ laser irradiation. b Temperature change in $\mathrm{Ag}_{2} \mathrm{~S} @$ BSA-SNO solution during $808 \mathrm{~nm}$ laser irradiation with different concentrations. $\mathrm{c}$ UV-Vis-NIR spectra of $\mathrm{Ag}_{2} \mathrm{~S} @ \mathrm{BSA}-\mathrm{SNO}$ solution with different concentrations. d Temperature variations of $\mathrm{Ag}_{2} \mathrm{~S} @ \mathrm{BSA}-\mathrm{SNO}$ under irradiation by $808 \mathrm{~nm}$ laser $\left(1.5 \mathrm{~W} \mathrm{~cm}^{-2}\right)$. e PA intensity of $\mathrm{Ag}_{2} \mathrm{~S} @$ BSA-SNO solution at near-infrared region. f PA signal of $\mathrm{Ag}_{2} \mathrm{~S} @ \mathrm{BSA}-\mathrm{SNO}$ solution (at $730 \mathrm{~nm}$ laser). $\mathbf{g}$ NO released under different temperatures. h $808 \mathrm{~nm}$ laser irradiation trigger NO release (red triangle means NIR stimulation). i Cell cloning statistics. The temperature caused by $808 \mathrm{~nm}$ laser is around $42{ }^{\circ} \mathrm{C}$, while the X-ray dose is $6 \mathrm{~Gy}$. $\mathbf{j}$, $\mathbf{k}$ Statistics and confocal laser scanning microscopy image of DNA damage staining after photothermal and irradiation therapeutics. Red: $\gamma$-H2AX signal (dsDNA damage staining); blue: DAPI (nuclear staining). Data are means $\pm \operatorname{SEM}(n \geq 3) . P$ value is based on student's $t$ test, with $* * * * P<0.0001$. (Color figure online)

S2), which can be used to real-time guide the precision radiotherapy in the future by NIR-II in vivo imaging [43, 48-53]. All these data indicated that $\mathrm{Ag}_{2} \mathrm{~S} @ \mathrm{BSA}-\mathrm{SNO}$ could be readily heated by NIR exposure and photoacoustic imaging of tumor.
We next assessed the triggered release of NO from $\mathrm{Ag}_{2} \mathrm{~S} @$ BSA-SNO NPs under $808 \mathrm{~nm}$ laser irradiation. The generated amounts of NO were determined by a classical Griess assay. As shown in Fig. 2g, we first observed that the NO was generated from $\mathrm{Ag}_{2} \mathrm{~S} @ \mathrm{BSA}-\mathrm{SNO}$ NPs when 
placed under 45 or $50^{\circ} \mathrm{C}$ condition, significantly higher than the samples in $37^{\circ} \mathrm{C}$, suggesting that higher temperature could promote the NO release. Importantly, the response release of NO was also achieved when exposed to $808 \mathrm{~nm}$ laser (Fig. 2h). Significant amounts of NO were generated from $\mathrm{Ag}_{2} \mathrm{~S} @$ BSA-SNO NPs when exposed to 808 nm laser irradiation. In contrast, few NO generation was detected in non-irradiated samples. All the data substantiated that the $\mathrm{Ag}_{2} \mathrm{~S} @ \mathrm{BSA}-\mathrm{SNO}$ could be used as NO delivery platform for controlled and precisely release of NO by NIR irradiation.

Next, we investigated the enlargement radiotherapy effects to kill cancer cell by $\mathrm{Ag}_{2} \mathrm{~S} @ \mathrm{BSA}-\mathrm{SNO}$ NPs in vitro. In our experiment, the cell viability test by means of cell colony formation assay (CFA) and $\gamma$-H2AX-based DNA damage assay were used to evaluate the tumor cells' proliferation under X-ray irradiation. As control experiment, no appreciable reduction in cell viabilities was noticed for cells incubated with plain $\mathrm{Ag}_{2} \mathrm{~S} @ \mathrm{BSA}-\mathrm{SNO}$ NPs by MTT assay at a concentration of $50 \mu \mathrm{g} \mathrm{mL}^{-1}$ (Fig. S3). As shown in Table S1, the nanoparticle solution with suitable concentration had a low hemolysis ratio, which was in the safe range. The hemolysis assay indicated that the nanoparticle did not damage blood cells at the current therapeutic dose. Next, CT-26 tumor cells were treated with $\mathrm{Ag}_{2} \mathrm{~S} @$ BSA-SNO NPs $\left(50 \mu \mathrm{g} \mathrm{mL}^{-1}\right) 4 \mathrm{~h}$ followed by X-ray. The formed cell colonies were counted after 5 days. Various control treatments were also conducted as shown in Fig. 2 i. The number of colonies in the control groups treated with $\mathrm{Ag}_{2} \mathrm{~S} @ \mathrm{BSA}-\mathrm{SNO}$ NPs + laser did not affect cell proliferation, indicating that neither thermal effect nor generated NO inhibited cell proliferation at the current dose. In addition, the X-ray (6 Gy)-treated group had a slightly lower number of cell colonies, which was consistent with the clinical result. As one kind of heavy metal, $\mathrm{Ag}_{2} \mathrm{~S} @ \mathrm{BSA}$ NPs with $\mathrm{X}$-rays significantly decreased the number of colonies. More importantly, the $\mathrm{Ag}_{2} \mathrm{~S} @ \mathrm{BSA}-\mathrm{SNO}$ NPs (+ laser) with X-rays group resulted in the lowest number of colonies. The proliferation of most cancer cells was totally inhibited (the cell survival rate $<2 \%$ ). To further prove the DNA damage level, the DNA damage staining by $\gamma$-H2AX was detected under confocal microscope (Fig. 2j-k and S4). The CT26 cells were immunostained with $\gamma-\mathrm{H} 2 \mathrm{AX}$ at $1 \mathrm{~h}$ post-treatments as indicated. Consistently, a marked increase in $\gamma$-H2AX foci was observed after $\mathrm{Ag}_{2} \mathrm{~S} @ \mathrm{BSA}-\mathrm{SNO}$ NPs (+ laser) with $\mathrm{X}$-rays treatment when compared to control cells. Our results showed that the $\mathrm{Ag}_{2} \mathrm{~S} @ \mathrm{BSA}-\mathrm{SNO}$ NPs could maximize radiotherapy effects by $\mathrm{Ag}_{2} \mathrm{~S}$ QDs and NO production by NIR exposure.

We next tested the capacity of $\mathrm{Ag}_{2} \mathrm{~S} @ \mathrm{BSA}-\mathrm{SNO}$ nanoparticles accumulated at the tumor site by EPR effect. In vivo PA imaging of tumor was recorded at pre-determined intervals (Fig. 3a). In our experiment, it was observed that in vivo PA signal peaked at $4 \mathrm{~h}$ and then gradually fell between 4 and $24 \mathrm{~h}$ (Fig. 3a, b) compared with PBS control, indicating that the NPs could accumulate at the tumor by EPR effect. Biodistribution study by ICP of Ag was also consistent with the PA in vivo imaging (Fig. S5). The tumors of mice receiving PBS or $\mathrm{Ag}_{2} \mathrm{~S} @ \mathrm{BSA}-\mathrm{SNO}$ nanoparticles administration at $4 \mathrm{~h}$ were irradiated by $808 \mathrm{~nm}$ laser. Remarkably increased temperature was observed at the tumor site of mice treated with $\mathrm{Ag}_{2} \mathrm{~S} @ \mathrm{BSA}-\mathrm{SNO}$ nanoparticles. All the data suggested that $\mathrm{Ag}_{2} \mathrm{~S} @ \mathrm{BSA}-\mathrm{SNO}$ nanoparticles accumulated at the tumor site could response to NIR exposure and generate mild heat $\left(\sim 45^{\circ} \mathrm{C}\right)$ to trigger NO generation. Notably, we checked the hypoxia of tumor microenvironment post-irradiation (Fig. S6). The immunofluorescence imaging of HIF-1 proved that mild photothermal effect reversed the hypoxia in tumor microenvironment, making tumor more sensitive to RT therapy.

To prove the enhanced anticancer therapy of radiation by our strategy, CT26 tumor-bearing mice received laser irradiation and X-ray irradiation sequentially after being injected with $\mathrm{Ag}_{2} \mathrm{~S} @ \mathrm{BSA}-\mathrm{SNO}$ nanoparticles for $4 \mathrm{~h}$. Mice that received other treatments were considered as controls. The tumor size was recorded every two days. As shown in Fig. 3e, compared with untreated group, mice injected with $\mathrm{Ag}_{2} \mathrm{~S} @ \mathrm{BSA}-\mathrm{SNO}$ with or without laser exposure showed no obvious tumor growth inhibition efficiency. The X-ray irradiation only slowed the tumor growth. The participation of $\mathrm{Ag}_{2} \mathrm{~S}$, mild heating and released NO further slowed down tumor growth partly. In contrast, the combination therapy $\left(\mathrm{Ag}_{2} \mathrm{~S} @ \mathrm{BSA}-\mathrm{SNO}\right.$ with laser $+\mathrm{X}$ ray) significantly inhibited the tumor growth. $60 \%$ of mice survived at least 30 days after combination treatment. In contrast, none of the mice survived in any of the control groups after one month (Fig. 3f). Toxic effects of $\mathrm{Ag}_{2} \mathrm{~S} @ \mathrm{BSA}-$ SNO nanoparticles were then evaluated after RT therapy. Body weights of mice were not significantly affected after various treatments (Fig. 3g). Histology analysis of organs also indicated no noticeable organ damage by analysis of H\&E staining (Fig. S7), indicating the minimal side effects induced by our strategy. It had been reported that the $\mathrm{Ag}_{2} \mathrm{~S}$ quantum dots can be excreted by urine and feces over 60 days without significant 
(a)
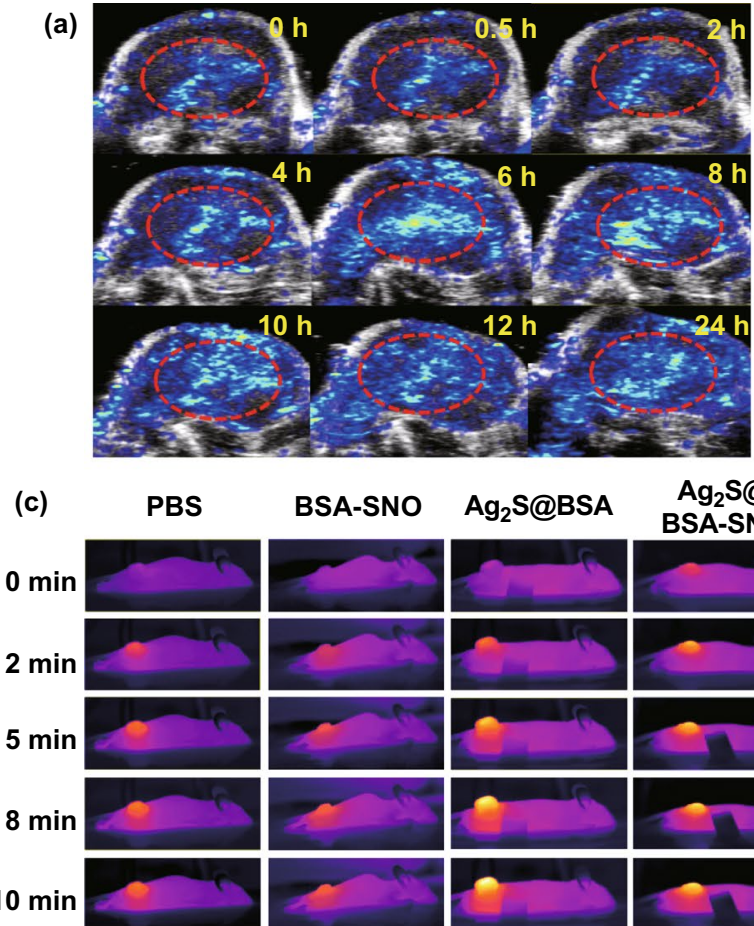

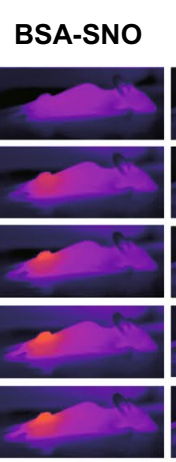

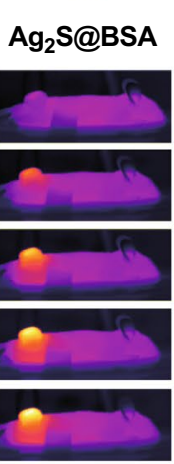

$20{ }^{\circ} \mathrm{C}$
$\mathrm{Ag}_{2} \mathrm{~S} @$ BSA-SNO

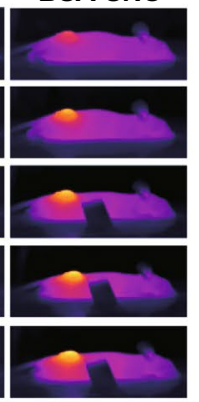

$50^{\circ} \mathrm{C}$
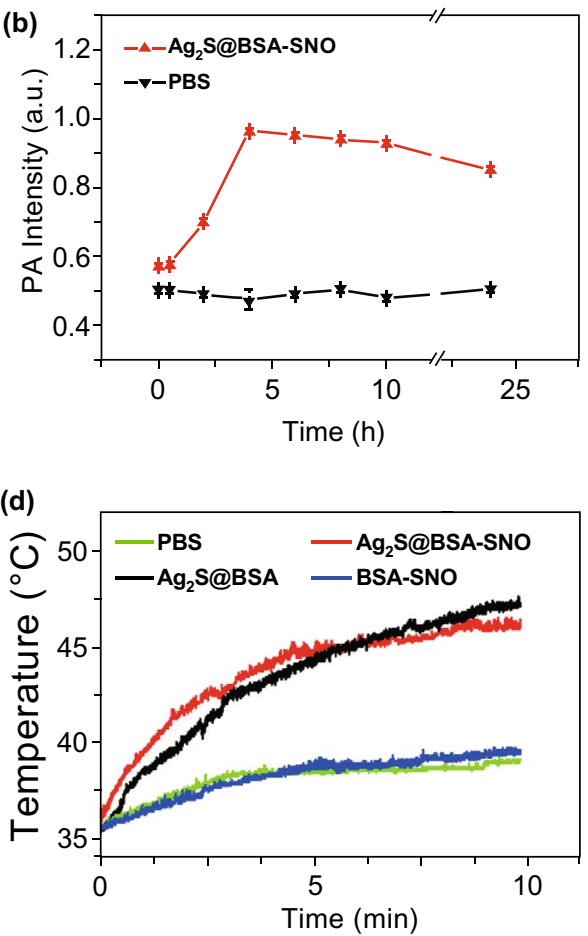

(e)

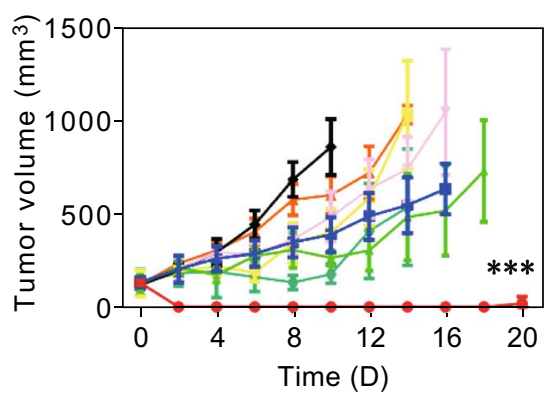

(g)

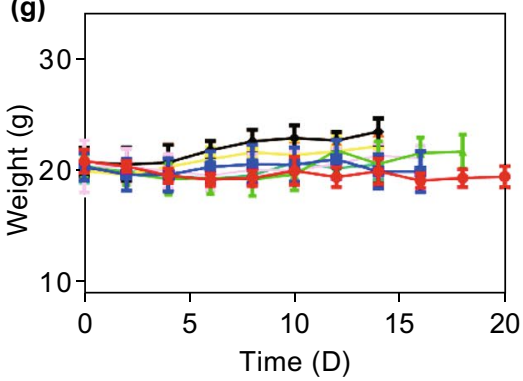

(f)

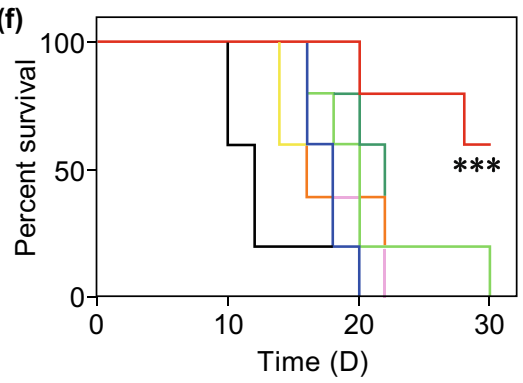

- Untreated

X-Ray

- $\mathrm{Ag}_{2} \mathrm{~S} @ B S A-S N O$

- $\mathrm{Ag}_{2} \mathrm{~S} @ B S A+L a s e r$

- $\mathrm{Ag}_{2} \mathrm{~S} @ B S A-S N O+X-R a y$

- $\mathrm{Ag}_{2} \mathrm{~S} @ B \mathrm{BSA}-\mathrm{SNO}+$ Laser

$-\mathrm{Ag}_{2} \mathrm{~S} @ B S A+L a s e r+X-R a y$

- $\mathrm{Ag}_{2} \mathrm{~S} @ B S A-S N O+L a s e r+X-R a y$

(h)

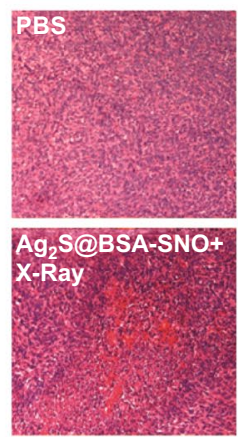

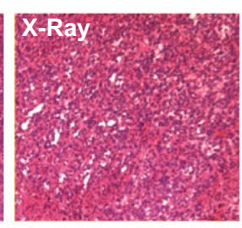
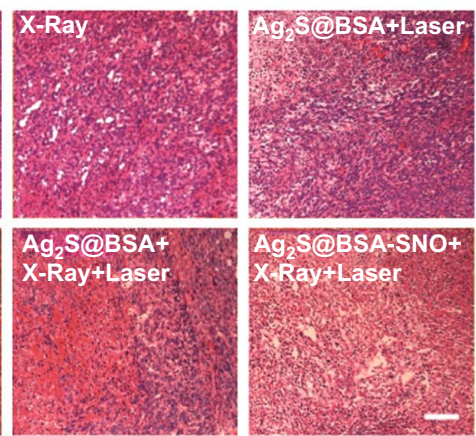
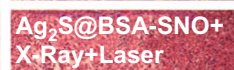
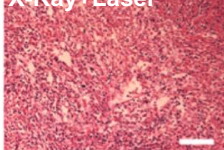

Fig. 3 Tumor targeting of $\mathrm{Ag}_{2} \mathrm{~S} @ \mathrm{BSA}-\mathrm{SNO}$ nanoparticles and in vivo radio enhancement therapy. a Local photoacoustic signal image in tumor at different time points after i.v. injection of $\mathrm{Ag}_{2} \mathrm{~S} @ \mathrm{BSA}-\mathrm{SNO}$ nanoparticles. b Quantitative data of photoacoustic signal according to a (PA image of PBS group is shown in supporting information). c Corresponding photothermal image of mice injected with different materials under NIR irradiation. d Temperature change curve of four groups according to $\mathbf{c}$. e Tumor growth curves of different groups of mice after various treatments. f Survival curves for the treated and control mice. $\mathbf{g}$ Body weight of mice after different treatments as indicated. $\mathbf{h} \mathrm{H} \& \mathrm{E}$ sections of tumor tissue after various treatments. Error bar is based on 5-6 mice per group. Data are means \pm SEM. Statistical significance was calculated by log-rank (Mantel-Cox) test. $* * * P<0.001$, and $* * P<0.1$. Scale bar is $100 \mu \mathrm{m}$ 
(a)
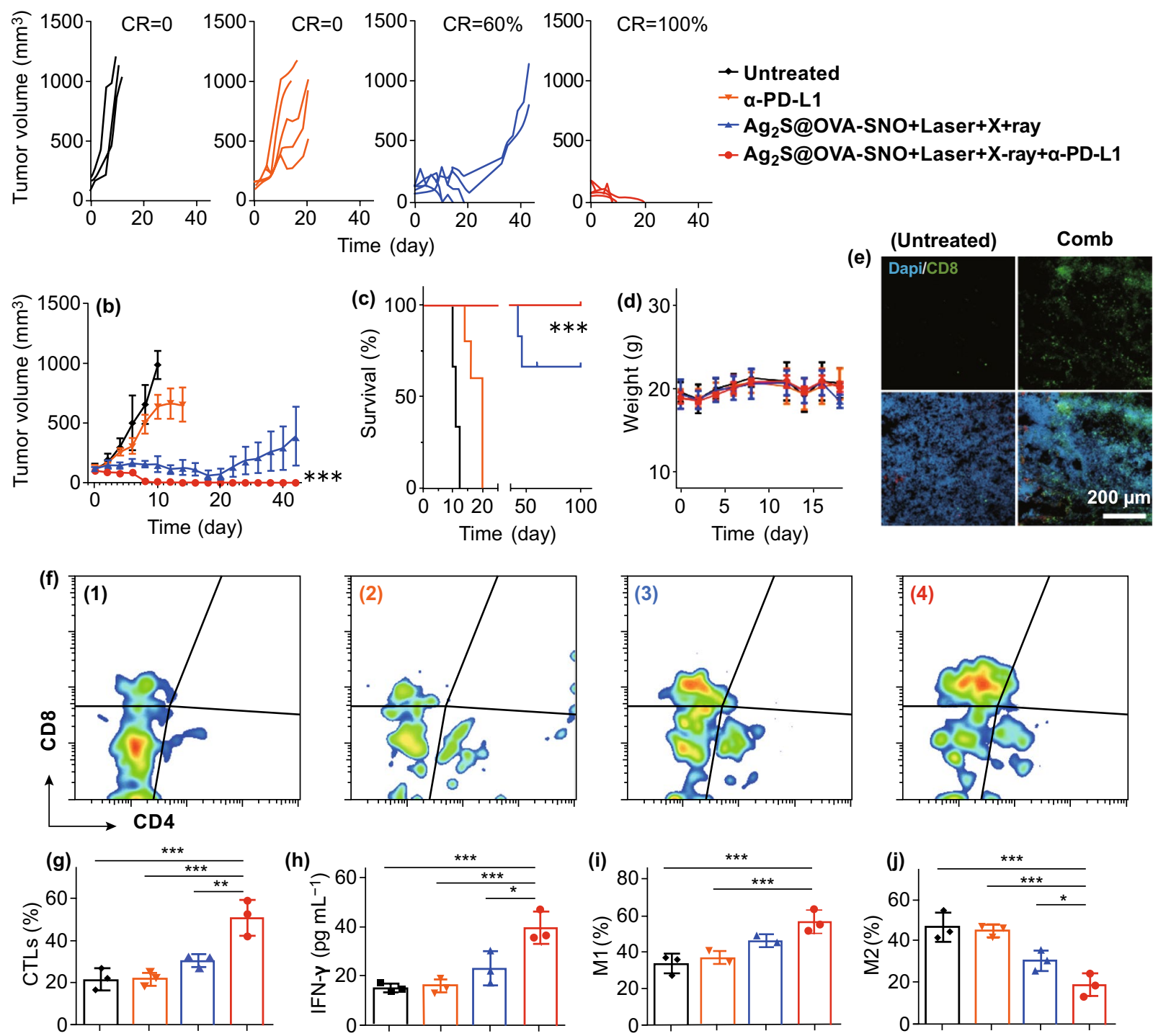

(1) (2) (3) (3)

(1) (2) (3) (3)

(1) (2) (3) (4)

(1) (2) (3) (4)

Fig. 4 Enhanced radioimmunotherapy in B16-OVA tumor models. a Single tumor growth curves of each group after various treatments as indicated. b Average tumor growth curves. c Survival curves for the treated and control mice. d Mice body weight change curves during 20 days after treatment as indicated. e Confocal image of tumor tissue sections after 4 days of cancer therapy. Green: CD8 positive cell signal; blue: DAPI (nuclear staining). f, g CTLs (CD3+ CD8+) in tumor tissues after 4 days of various treatments by flow cytometric analysis. $\mathbf{h}$ Cell cytokine levels of serum in different groups mice. $\mathbf{i}, \mathbf{j}$ Flow cytometric analysis of the percentage of macrophages in tumor tissue of different groups. Error bars are based on three mice per group. Data are means \pm SEM. For $(\mathbf{g}-\mathbf{j})$, statistical significance was calculated by oneway ANOVA with Tukey's post hoc test. For c, statistical significance was calculated by log-rank (Mantel-Cox) test. $* P<0.05$; $* * P<0.01$. $* * * P<0.005$. (Color figure online)

toxicity [54-56]. Nevertheless, long-term toxic effect study is needed in the further research.

There has been reported that RT, mild heating as well as nitric oxide make tumor more responsive to immunotherapy $[57,58,11]$.We next studied the anticancer immune response induced by our enhanced RT therapy. OVA is a
T-cell-dependent antigen commonly used as a model protein for studying antigen-specific immune responses in mice. Here, we demonstrated that in addition to BSA, tumor antigen such as OVA can be used to modify our NPs to induce a tumor antigen-specific immune response. We used OVA instead of BSA to modify the $\mathrm{Ag}_{2} \mathrm{~S}$ NPs to form the $\mathrm{Ag}_{2} \mathrm{~S} @ \mathrm{OVA}-\mathrm{SNO}$ 
nanoparticles (Fig. S2). B16F10-OVA tumor-bearing B6 mice were treated with anti-PD-L1, $\mathrm{Ag}_{2} \mathrm{~S} @ \mathrm{OVA}-\mathrm{SNO}+$ laser with $\mathrm{X}$-ray, or the combination of radioimmunotherapy. Excitingly, we found that anti-PD-L1 further promoted anticancer effects in B16-bearing mice with $\mathrm{Ag}_{2} \mathrm{~S} @ \mathrm{OVA}-\mathrm{SNO}$ plus laser and X-ray treatment (Fig. 4a, b). More importantly, $100 \%$ of mice were survived at least 100 days (Fig. 4c) without obvious side effects (Fig. 4d), suggesting a high efficacy to treat tumor by our enhanced radioimmunotherapy. Furthermore, tumors were harvested and analyzed by immunofluorescence and flow cytometry on day 4 after treatments. Remarkably, infiltration of CD8+ T cells was observed under fluorescence microscope in the tumor tissue of mice that received combination therapy compared to the untreated mice (Fig. 4e). The analysis by flow cytometry showed that the percentage of CTL cells increased more than twofold compared with controls (Fig. 4f-g). In addition, the Interferon gamma (IFN- $\gamma$ ) level was also found increased after combination therapy (Fig. 4h). M1 and M2-polarized macrophage were also examined. Interestingly, the surface expression of CD80 was up-regulated while the CD206 was down-regulated in comb treated group compared with other control groups, indicating that our strategy could also improve the anticancer effects by regulating the macrophage polarization to M1-like (Fig. 4i, j). Together, these observations suggested that $\mathrm{Ag}_{2} \mathrm{~S} @ \mathrm{OVA}-\mathrm{SNO}+$ laser with $\mathrm{X}$-ray in combination with anti-PD-L1 triggered a robust antitumor immune response.

\section{Conclusions}

As a conclusion, we successfully synthesized a NO delivery system based on $\mathrm{Ag}_{2} \mathrm{~S}$ QDs for controlled and precisely release of NO to enhance cancer radioimmunotherapy. In this system, protein was used to provide space for $\mathrm{Ag}_{2} \mathrm{~S}$ QDs formation, which was coupled with NO donor TBN to generate nitric oxide by NIR exposure. Enhanced radiotherapy caused by nitric oxide and $\mathrm{Ag}_{2} \mathrm{~S}$ QDs inhibited the CT26 tumor remarkably in vitro and in vivo. Furthermore, we demonstrated that by tumor antigen OVA modification, the $\mathrm{Ag}_{2} \mathrm{~S} @ \mathrm{OVA}-\mathrm{SNO}$ was a promise platform to enhance the antitumor immune response with a high efficacy. $100 \%$ survival rate was achieved by our radio-immune combined therapy strategy in mice model. Therefore, such a protein carrier NIR-triggered NO delivery nanoparticles would allow lowdose radiation to treat cancer, enhancing the immunogenic tumor phenotype and promoting the response of immune checkpoint blockade therapy. In addition, the system can not only be applied in cancer treatment but also useful to treat some other diseases by NO delivery.

Acknowledgements This work is supported by grants from startup supports of Soochow University and the Program for Jiangsu Specially Appointed Professors to C. W. This work is partly supported by Collaborative Innovation Center of Suzhou Nano Science \& Technology, the Priority Academic Program Development of Jiangsu Higher Education Institutions (PAPD), the 111 Project. This work was also supported by the National Natural Science Foundation of China (No. 31900988), the Natural Science Foundation of Jiangsu Province (No. SBK2019040088) and Jiangsu Province Six Talent Peaks Project (No. SWYY-110).

Author Contributions CW, ZM and XZ designed the project. $\mathrm{XZ}$ and $\mathrm{ZM}$ performed the experiments and collected the data. All authors analyzed and interpreted the data, contributed to the writing of the manuscript, discussed the results and implications, and edited the manuscript at all stages.

Open Access This article is licensed under a Creative Commons Attribution 4.0 International License, which permits use, sharing, adaptation, distribution and reproduction in any medium or format, as long as you give appropriate credit to the original author(s) and the source, provide a link to the Creative Commons licence, and indicate if changes were made. The images or other third party material in this article are included in the article's Creative Commons licence, unless indicated otherwise in a credit line to the material. If material is not included in the article's Creative Commons licence and your intended use is not permitted by statutory regulation or exceeds the permitted use, you will need to obtain permission directly from the copyright holder. To view a copy of this licence, visit http://creativecommons.org/licenses/by/4.0/.

Electronic supplementary material The online version of this article (https://doi.org/10.1007/s40820-020-00431-3) contains supplementary material, which is available to authorized users.

\section{References}

1. R.N. Kjellberg, Radiation therapy. Science 176(4039), 10711071 (1972). https://doi.org/10.1126/science.176.4039.1071

2. M.J. O'Connor, Targeting the DNA damage response in cancer. Mol. Cell 60(4), 547-560 (2015). https://doi. org/10.1016/j.molcel.2015.10.040

3. R. Atun, D.A. Jaffray, M.B. Barton, F. Bray, M. Baumann et al., Expanding global access to radiotherapy. Lancet Oncol. 16(10), 1153-1186 (2015). https://doi.org/10.1016/s1470 $-2045(15) 00222-3$

4. S. Siva, M.P. MacManus, R.F. Martin, O.A. Martin, Abscopal effects of radiation therapy: a clinical review for the 
radiobiologist. Cancer Lett. 356(1), 82-90 (2015). https://doi. org/10.1016/j.canlet.2013.09.018

5. H.E. Barker, J.T.E. Paget, A.A. Khan, K.J. Harrington, The tumour microenvironment after radiotherapy: mechanisms of resistance and recurrence. Nat. Rev. Cancer 15(7), 409-425 (2015). https://doi.org/10.1038/nrc3958

6. G.S. Song, L. Cheng, Y. Chao, K. Yang, Z. Liu, Emerging nanotechnology and advanced materials for cancer radiation therapy. Adv. Mater. 29(32), 26 (2017). https://doi. org/10.1002/adma.201700996

7. P. Retif, S. Pinel, M. Toussaint, C. Frochot, R. Chouikrat, T. Bastogne, M. Barberi-Heyob, Nanoparticles for radiation therapy enhancement: the key parameters. Theranostics 5(9), 1030-1045 (2015). https://doi.org/10.7150/thno.11642

8. S. Her, D.A. Jaffray, C. Allen, Gold nanoparticles for applications in cancer radiotherapy: Mechanisms and recent advancements. Adv. Drug Del. Rev. 109, 84-101 (2017). https://doi. org/10.1016/j.addr.2015.12.012

9. B. Bonavida, S. Khineche, S. Huerta-Yepez, H. Garbán, Therapeutic potential of nitric oxide in cancer. Drug Resist. Updates 9(3), 157-173 (2006). https://doi.org/10.1016/j. drup.2006.05.003

10. H. Yasuda, Solid tumor physiology and hypoxia-induced chemo/radio-resistance: novel strategy for cancer therapy: Nitric oxide donor as a therapeutic enhancer. Nitric Oxide 19(2), 205-216 (2008). https://doi.org/10.1016/j. niox.2008.04.026

11. Y.-C. Sung, P.-R. Jin, L.-A. Chu, F.-F. Hsu, M.-R. Wang et al., Delivery of nitric oxide with a nanocarrier promotes tumour vessel normalization and potentiates anti-cancer therapies. Nat. Nanotechnol. 14, 1160-1169 (2019). https://doi. org/10.1038/s41565-019-0570-3

12. Q. Song, S. Tan, X. Zhuang, Y. Guo, Y. Zhao, T. Wu, Q. Ye, L. Si, Z. Zhang, Nitric oxide releasing d- $\alpha$-tocopheryl polyethylene glycol succinate for enhancing antitumor activity of doxorubicin. Mol. Pharm. 11(11), 4118-4129 (2014). https:// doi.org/10.1021/mp5003009

13. J. Fan, Q. He, Y. Liu, F. Zhang, X. Yang et al., Light-responsive biodegradable nanomedicine overcomes multidrug resistance via NO-enhanced chemosensitization. ACS Appl. Mater. Interfaces 8(22), 13804-13811 (2016). https://doi. org/10.1021/acsami.6b03737

14. M. De Ridder, D. Verellen, V. Verovski, G. Storme, Hypoxic tumor cell radiosensitization through nitric oxide. Nitric Oxide 19(2), 164-169 (2008). https://doi.org/10.1016/j. niox.2008.04.015

15. F. Frérart, P. Sonveaux, G. Rath, A. Smoos, A. Meqor et al., The acidic tumor microenvironment promotes the reconversion of nitrite into nitric oxide: towards a new and safe radiosensitizing strategy. Clin. Cancer Res. 14(9), 2768-2774 (2008). https://doi.org/10.1158/1078-0432.CCR-07-4001

16. W. Fan, W. Bu, Z. Zhang, B. Shen, H. Zhang et al., X-ray radiation-controlled NO-release for on-demand depth-independent hypoxic radiosensitization. Angew. Chem. Int. Ed. 54(47), 14026-14030 (2015). https://doi.org/10.1002/anie.201504536

17. P.G. Wang, M. Xian, X. Tang, X. Wu, Z. Wen, T. Cai, A.J. Janczuk, Nitric oxide donors: chemical activities and biological applications. Chem. Rev. 102(4), 1091-1134 (2002). https ://doi.org/10.1021/cr0000401

18. J. Xu, F. Zeng, H. Wu, C. Hu, C. Yu, S. Wu, Preparation of a mitochondria-targeted and NO-releasing nanoplatform and its enhanced pro-apoptotic effect on cancer cells. Small 10(18), 3750-3760 (2014). https://doi.org/10.1002/smll.201400437

19. S.P. Hussain, G.E. Trivers, L.J. Hofseth, P. He, I. Shaikh et al., Nitric oxide, a mediator of inflammation, suppresses tumorigenesis. Cancer Res. 64(19), 6849-6853 (2004). https://doi. org/10.1158/0008-5472.CAN-04-2201

20. C. Bogdan, Nitric oxide and the immune response. Nat. Immunol. 2(10), 907-916 (2001). https://doi.org/10.1038/ni100 $1-907$

21. C. Fionda, M.P. Abruzzese, A. Santoni, M. Cippitelli, Immunoregulatory and effector activities of nitric oxide and reactive nitrogen species in cancer. Curr. Med. Chem. 23(24), 2618 2636 (2016). https://doi.org/10.2174/09298673236661607271 05101

22. A.W. Carpenter, M.H. Schoenfisch, Nitric oxide release: Part II. Therapeutic applications. Chem. Soc. Rev. 41(10), 37423752 (2012). https://doi.org/10.1039/C2CS15273H

23. K. Sato, K. Ozaki, I. Oh, A. Meguro, K. Hatanaka, T. Nagai, K. Muroi, K. Ozawa, Nitric oxide plays a critical role in suppression of T-cell proliferation by mesenchymal stem cells. Blood 109(1), 228-234 (2007). https://doi.org/10.1182/blood $-2006-02-002246$

24. Z. Huang, J. Fu, Y. Zhang, Nitric oxide donor-based cancer therapy: advances and prospects. J. Med. Chem. 60(18), 76177635 (2017). https://doi.org/10.1021/acs.jmedchem.6b01672

25. J.W. Wiley, The many faces of nitric oxide: cytotoxic, cytoprotective or both. Neurogastroenterol. Motil. 19(7), 541-544 (2007). https://doi.org/10.1111/j.1365-2982.2007.00958.x

26. J.F. Quinn, M.R. Whittaker, T.P. Davis, Delivering nitric oxide with nanoparticles. J. Control. Release 205, 190-205 (2015). https://doi.org/10.1016/j.jconrel.2015.02.007

27. X. Jia, Y. Zhang, Y. Zou, Y. Wang, D. Niu et al., Dual intratumoral redox/enzyme-responsive NO-releasing nanomedicine for the specific, high-efficacy, and low-toxic cancer therapy. Adv. Mater. 30(30), 1704490 (2018). https://doi.org/10.1002/ adma.201704490

28. R. Yahyapour, E. Motevaseli, A. Rezaeyan, H. Abdollahi, B. Farhood et al., Reduction-oxidation (redox) system in radiation-induced normal tissue injury: molecular mechanisms and implications in radiation therapeutics. Clin. Transl. Oncol. 20(8), 975-988 (2018). https://doi.org/10.1007/s1209 4-017-1828-6

29. L. Tian, Y. Wang, L. Sun, J. Xu, Y. Chao, K. Yang, S. Wang, Z. Liu, Cerenkov luminescence-induced NO release from ${ }^{32} \mathrm{P}$-Labeled $\mathrm{ZnFe}(\mathrm{CN})_{5} \mathrm{NO}$ nanosheets to enhance 
radioisotope-immunotherapy. Matter 1(4), 1061-1076 (2019). https://doi.org/10.1016/j.matt.2019.07.007

30. Y. Deng, F. Jia, S. Chen, Z. Shen, Q. Jin, G. Fu, J. Ji, Nitric oxide as an all-rounder for enhanced photodynamic therapy: hypoxia relief, glutathione depletion and reactive nitrogen species generation. Biomaterials 187, 55-65 (2018). https://doi. org/10.1016/j.biomaterials.2018.09.043

31. M. Feelisch, The use of nitric oxide donors in pharmacological studies. Naunyn-Schmiedeberg's Arch. Pharmacol 358(1), 113-122 (1998). https://doi.org/10.1007/p100005231

32. A. Fraix, S. Sortino, Photoactivable platforms for nitric oxide delivery with fluorescence imaging. Chem. Asian J. 10(5), 1116-1125 (2015). https://doi.org/10.1002/asia.201403398

33. B. Bonavida, S. Baritaki, S. Huerta-Yepez, M.I. Vega, D. Chatterjee, K. Yeung, Novel therapeutic applications of nitric oxide donors in cancer: roles in chemo- and immunosensitization to apoptosis and inhibition of metastases. Nitric Oxide 19(2), 152-157 (2008). https://doi.org/10.1016/j.niox.2008.04.018

34. J. Fan, N. He, Q. He, Y. Liu, Y. Ma et al., A novel self-assembled sandwich nanomedicine for NIR-responsive release of NO. Nanoscale 7(47), 20055-20062 (2015). https://doi. org/10.1039/c5nr06630a

35. C. Oliveira, S. Benfeito, C. Fernandes, F. Cagide, T. Silva, F. Borges, NO and HNO donors, nitrones, and nitroxides: past, present, and future. Med. Res. Rev. 38(4), 1159-1187 (2018). https://doi.org/10.1002/med.21461

36. H.W. Choi, J. Kim, J. Kim, Y. Kim, H.B. Song, J.H. Kim, K. Kim, W.J. Kim, Light-induced acid generation on a gatekeeper for smart nitric oxide delivery. ACS Nano 10(4), 4199-4208 (2016). https://doi.org/10.1021/acsnano.5b07483

37. L. Tan, R. Huang, X. Li, S. Liu, Y.M. Shen, Controllable release of nitric oxide and doxorubicin from engineered nanospheres for synergistic tumor therapy. Acta Biomater. 57, 498-510 (2017). https://doi.org/10.1016/j.actbio.2017.05.019

38. J. Kim, B.C. Yung, W.J. Kim, X. Chen, Combination of nitric oxide and drug delivery systems: tools for overcoming drug resistance in chemotherapy. J. Control. Release 263, 223-230 (2017). https://doi.org/10.1016/j.jconrel.2016.12.026

39. L. Chen, Q. He, M. Lei, L. Xiong, K. Shi, L. Tan, Z. Jin, T. Wang, Z. Qian, Facile coordination-precipitation route to insoluble metal roussin's black salts for NIR-responsive release of NO for anti-metastasis. ACS Appl. Mater. Interfaces 9(42), 36473-36477 (2017). https://doi.org/10.1021/ acsami.7b11325

40. W. Fan, N. Lu, P. Huang, Y. Liu, Z. Yang et al., Glucoseresponsive sequential generation of hydrogen peroxide and nitric oxide for synergistic cancer starving-like/gas therapy. Angew. Chem. Int. Ed. 56(5), 1229-1233 (2017). https://doi. org/10.1002/anie.201610682

41. K. Zhang, H. Xu, X. Jia, Y. Chen, M. Ma, L. Sun, H. Chen, Ultrasound-triggered nitric oxide release platform based on energy transformation for targeted inhibition of pancreatic tumor. ACS Nano 10(12), 10816-10828 (2016). https://doi. org/10.1021/acsnano.6b04921

42. Z. Jin, Y. Wen, Y. Hu, W. Chen, X. Zheng et al., MRI-guided and ultrasound-triggered release of NO by advanced nanomedicine. Nanoscale 9(10), 3637-3645 (2017). https://doi. org/10.1039/c7nr00231a

43. T. Yang, Y. Tang, L. Liu, X. Lv, Q. Wang et al., Size-dependent $\mathrm{Ag}_{2} \mathrm{~S}$ nanodots for second near-infrared fluorescence/photoacoustics imaging and simultaneous photothermal therapy. ACS Nano 11(2), 1848-1857 (2017). https://doi.org/10.1021/ acsnano.6b07866

44. R. Guo, Y. Tian, Y. Wang, W. Yang, Near-infrared laser-triggered nitric oxide nanogenerators for the reversal of multidrug resistance in cancer. Adv. Funct. Mater. 27(13), 1606398 (2017). https://doi.org/10.1002/adfm.201606398

45. L. Tan, A. Wan, X. Zhu, H. Li, Visible light-triggered nitric oxide release from near-infrared fluorescent nanospheric vehicles. Analyst 139(13), 3398-3406 (2014). https://doi. org/10.1039/c4an00275j

46. H.-J. Xiang, M. Guo, L. An, S.-P. Yang, Q.-L. Zhang, J.-G. Liu, A multifunctional nanoplatform for lysosome targeted delivery of nitric oxide and photothermal therapy under 808 nm near-infrared light. J. Mater. Chem. B 4(27), 4667-4674 (2016). https://doi.org/10.1039/c6tb00730a

47. X. Zhang, G. Tian, W. Yin, L. Wang, X. Zheng et al., Controllable generation of nitric oxide by near-infrared-sensitized upconversion nanoparticles for tumor therapy. Adv. Funct. Mat. 25(20), 3049-3056 (2015). https://doi.org/10.1002/ adfm.201404402

48. X. Hao, C. Li, Y. Zhang, H. Wang, G. Chen, M. Wang, Q. Wang, Programmable chemotherapy and immunotherapy against breast cancer guided by multiplexed fluorescence imaging in the second near-infrared window. Adv. Mater. 30(51), 1804437 (2018). https://doi.org/10.1002/adma.20180 4437

49. J. Gao, C. Wu, D. Deng, P. Wu, C. Cai, Direct synthesis of water-soluble aptamer- $\mathrm{Ag}_{2} \mathrm{~S}$ quantum dots at ambient temperature for specific imaging and photothermal therapy of cancer. Adv. Healthc. Mater. 5(18), 2437-2449 (2016). https://doi. org/10.1002/adhm.201600545

50. G.M. Neelgund, M.C. Okolie, F.K. Williams, A.J.M.C. Oki, Physics, $\mathrm{Ag}_{2} \mathrm{~S}$ nanocrystallites deposited over polyamidoamine grafted carbon nanotubes: an efficient NIR active photothermal agent. Mater. Chem. Phys. 234, 32-37 (2019). https ://doi.org/10.1016/j.matchemphys.2019.05.040

51. D.-H. Zhao, J. Yang, R.-X. Xia, M.-H. Yao, R.-M. Jin, Y.-D. Zhao, B.J.C.C. Liu, High quantum yield $\mathrm{Ag}_{2} \mathrm{~S}$ quantum dot@ polypeptide-engineered hybrid nanogels for targeted second near-infrared fluorescence/photoacoustic imaging and photothermal therapy. Chem. Commun. 54(5), 527-530 (2018). https://doi.org/10.1016/j.matchemphys.2019.05.040 
52. Y. Du, B. Xu, T. Fu, M. Cai, F. Li, Y. Zhang, Q. Wang, Nearinfrared photoluminescent $\mathrm{Ag}_{2} \mathrm{~S}$ quantum dots from a single source precursor. J. Am. Chem. Soc. 132(5), 1470-1471 (2010). https://doi.org/10.1021/ja909490r

53. Y. Shen, J. Lifante, E. Ximendes, H.D. Santos, D. Ruiz et al., Perspectives for $\mathrm{Ag}_{2} \mathrm{~S}$ NIR-II nanoparticles in biomedicine: from imaging to multifunctionality. Nanoscale 11(41), 1925119264 (2019). https://doi.org/10.1039/C9NR05733A

54. Y. Zhang, Y. Zhang, G. Hong, W. He, K. Zhou et al., Biodistribution, pharmacokinetics and toxicology of $\mathrm{Ag}_{2} \mathrm{~S}$ near-infrared quantum dots in mice. Biomaterials 34(14), 3639-3646 (2013). https://doi.org/10.1016/j.biomaterials.2013.01.089

55. G. Hong, J.T. Robinson, Y. Zhang, S. Diao, A.L. Antaris, Q. Wang, H. Dai, In vivo fluorescence imaging with $\mathrm{Ag}_{2} \mathrm{~S}$ quantum dots in the second near-infrared region. Angew. Chem. Int. Ed. 51(39), 9818-9821 (2012). https://doi.org/10.1002/ anie. 201206059
56. J. Javidi, A. Haeri, F. Nowroozi, S. Dadashzadeh, Pharmacokinetics, Tissue distribution and excretion of $\mathrm{Ag}_{2} \mathrm{~S}$ quantum dots in mice and rats: the effects of injection dose, particle size and surface charge. Pharm. Res. 36(3), 46 (2019). https://doi. org/10.1007/s11095-019-2571-1

57. L. Huang, Y. Li, Y. Du, Y. Zhang, X. Wang et al., Mild photothermal therapy potentiates anti-PD-L1 treatment for immunologically cold tumors via an all-in-one and all-in-control strategy. Nat. Commun. 10(1), 1-15 (2019). https://doi. org/10.1038/s41467-019-12771-9

58. K. Ni, G. Lan, C. Chan, B. Quigley, K. Lu et al., Nanoscale metal-organic frameworks enhance radiotherapy to potentiate checkpoint blockade immunotherapy. Nat. Commun. 9(1), 2351 (2018). https://doi.org/10.1038/s41467-018-04703-w 